\title{
$\beta$-glucuronidase activity of lymph node imprints from malignant lymphomas and chronic lymphocytic leukaemia
}

\author{
G. A. PANGAlis, X. YATAGANAS, AND PH. FESSAS \\ From the First Department of Internal Medicine, University of Athens Medical School, Vassilevs Pavlos \\ Hospital, Athens, Greece
}

SUMMARY $\beta$-Glucuronidase activity was semiquantitatively estimated in the cells of lymph node (LN) imprints from patients with Hodgkin's disease(HD), diffusenon-Hodgkin'slymphomas, chronic lymphocytic leukaemia (CLL), normal lymph nodes, and benign lymphadenopathies. In addition, in some of these cases $\beta$-glucuronidase activity was semiquantitatively determined in peripheral blood smear lymphocytes. The $\beta$-glucuronidase score $(\beta \mathrm{GS})$ was very low in the cells of the $\mathrm{LN}$ imprints from patients with diffuse non-Hodgkin's lymphomas. The LN lymphocytes of HD had a normal $\beta \mathrm{GS}$ independently of the histological subtype of the disease, while in the LN imprint of CLL the enzyme activity was low, normal, or high. The $\beta G S$ of the lymphocytes in LN imprints of normal controls and HD were in general significantly lower compared with the lymphocytes of the peripheral blood smears in the same cases. The relation of our findings to the $B$ and $T$ cell origin os malignant lymphomas and chronic lymphocytic leukaemia is discussed.

$\beta$-Glucuronidase is a hydrolytic lysosomal enzyme present in normal lymphocytes (Lorbacher et al., 1967; Yam and Mitus, 1968). Its activity has been semiquantitatively estimated in normal circulating lymphocytes and various degrees of positivity have been found (Yam and Mitus, 1968; Flandrin and Daniel, 1974). Peripheral blood lymphocytes from patients with non-Hodgkin's lymphomas and patients with chronic lymphocytic leukaemia (CLL) had a lower $\beta$-glucuronidase activity compared with lymphocytes from normal subjects and patients with Hodgkin's disease (HD) (Anlyan et al., 1950; Follette et al., 1952; Yam and Mitus, 1968; Brittinger et al., 1970; Douglas et al., 1973; Flandrin and Daniel, 1974; Westerhausen, 1973; Woessner et al., 1974). Crowder and White (1968), however, found normal $\beta$-glucuronidase activity in CLL lymphocytes. These conflicting results and the lack of a semiquantitative study of $\beta$-glucuronidase activity in lymph node ( $L N)$ imprints in lymphoproliferative disorders prompted us to investigate (1) whether the activity of this enzyme in cases of malignant lymphocytic proliferation differs from that in benign lymphocytic proliferation, (2) whether it differs in the LN imprint cells and the peripheral blood

Received for publication 14 April 1977 lymphocytes in the same cases, and (3) whether it is related to the B or T cell origin of neoplastic lymphoid malignancies.

\section{Patients and methods}

A total of 64 patients admitted to the First Department of Internal Medicine, Athens University, during the 12 months June 1973 - May 1974 were subjected to diagnostic LN biopsy. Out of these 64 patients 49 were admitted to the study. Mesenteric lymph nodes from an additional 14 patients undergoing abdominal surgery for non-malignant and 9 non-acute inflammatory disorders were used as controls. All $63 \mathrm{LN}$ specimens were obtained in the fresh state and numerous touch imprints were made from each specimen. The lymph nodes were then 5 fixed in buffered formalin solution and sections cut $N$ at $5 \mu \mathrm{m}$ and stained with haematoxylin and eosin. Imprints were stained with May-Grünwald-Giemsa 우 for morphological evaluation of the cell type.

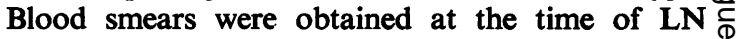
biopsy from three patients with diffuse lymphocytic, 足 poorly differentiated malignant lymphoma (DLPD); 0 five patients with diffuse lymphocytic, well differ- $\vec{O}$ entiated malignant lymphoma (DLWD); four $\stackrel{\odot}{\Phi}$

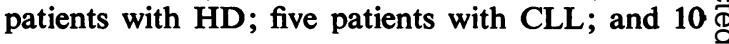


Table Data on the cases of 49 patients with malignant lymphoproliferative disease and 14 persons with no malignancy (controls)

\begin{tabular}{|c|c|c|c|c|}
\hline \multirow[t]{2}{*}{ Histological diagnosis } & \multirow[t]{2}{*}{ No. of cases } & \multirow{2}{*}{$\begin{array}{l}\text { Mean age } \\
\text { (range) }\end{array}$} & \multicolumn{2}{|c|}{$\operatorname{Sex}$} \\
\hline & & & $M$ & $F$ \\
\hline Controls & 14 & $\begin{array}{l}53 \\
(32-68)\end{array}$ & 6 & 8 \\
\hline Non-specific reactive follicular hyperplasia & 8 & $\begin{array}{l}43 \\
(12-59)\end{array}$ & 4 & 4 \\
\hline $\begin{array}{l}\text { Tuberculosis } \\
\text { Sarcoidosis } \\
\text { Leishmaniasis (L. Donovani) }\end{array}$ & $\begin{array}{l}3 \\
3 \\
2\end{array}$ & $\begin{array}{l}19,58,60 \\
45,60,68 \\
19,31\end{array}$ & $\begin{array}{l}2 \\
1 \\
1\end{array}$ & $\begin{array}{l}1 \\
2 \\
1\end{array}$ \\
\hline Malignant lymphomas* & & & & \\
\hline Hodgkin's disease & 10 & $\begin{array}{l}30 \\
(16-65)\end{array}$ & 5 & 5 \\
\hline $\begin{array}{l}\text { Non-Hodgkin's lymphomas } \\
\text { Diffuse lymphocytic, well differentiated }\end{array}$ & 7 & $\begin{array}{l}66 \\
(38-72)\end{array}$ & 4 & 3 \\
\hline Diffuse lymphocytic, poorly differentiated & 7 & 53 & 4 & 3 \\
\hline $\begin{array}{l}\text { Diffuse histiocytic } \\
\text { Chronic lymphocytic leukaemia } †\end{array}$ & $\begin{array}{l}2 \\
7\end{array}$ & $\begin{array}{l}58,72 \\
62 \\
(51-82)\end{array}$ & $\begin{array}{l}1 \\
6\end{array}$ & $\begin{array}{l}1 \\
1\end{array}$ \\
\hline
\end{tabular}

* Three cases of lymphocytic predominance type, six cases of nodular sclerosis type, one case of mixed cell type.

† Absolute lymphocytes ranged from 10000 to $130000 / \mathrm{mm}^{3}$. All cases with significant generalised lymphadenopathy and spleno or heptatomegaly, or both.

controls. The age, sex, and histological diagnosis of all the patients studied are shown in the Table. Cases of DLWD were distinguished from those of CLL and Waldenström's macroglobulinaemia by the haematological and immunoelectrophoretic findings (Pangalis et al., 1977b). The diagnosis of tuberculosis was confirmed by culture studies, while the diagnosis of sarcoidosis was supported by clinical and laboratory studies.

CYTOCHEMICAL STUDY

$\beta$-Glucuronidase activity was measured by the cytochemical method described by Hayashi et al. (1964) and Lorbacher et al. (1967). One hundred peripheral blood lymphocytes were examined and graded from 0 to $4 \pm$ according to the degree of reaction positivity after counterstaining with methyl green (Yam and Mitus, 1968). In the LN imprints, however, 400 cells were evaluated. In normal LN, benign lymphadenopathies and Hodgkin's disease this evaluation was limited to lymphocytes. In the LN imprints from non-Hodgkin's lymphomas and CLL all cells were available because from the tissue sections the number of apparently normal lymphocytes was either negligible or, in DLWD and CLL, could not be separated morphologically from the neoplastic cells.

The cells of the imprints were counterstained with methyl-green, which enabled the $\beta$-glucuronidase positivity to be measured concomitantly with the morphological identification of the individual cells.

\section{Results}

The end product of $\beta$-glucuronidase reaction was easily recognised as discrete small reddish granules in the cytoplasm of the cells. The interpretations of reaction positivity were the same both before and after methyl-green counterstaining.

\section{$\beta$-GLUCURONIDASE ACTIVITY IN LN IMPRINTS}

\section{Controls and benign lymphadenopathies}

The lymphocytes of the normal mesenteric LN had an average $\beta \mathrm{GS}$ of $60.5 \pm 21.8$ (range 3-93) and an average of $48 \%$ positive cells (range $30-75 \%$ ). The $\beta \mathrm{GS}$ of the lymphocytes from the non-specific reactive $L N$ as well as from the $L N$ of tuberculosis; sarcoidosis, and one case of leishmaniasis was within the range of the control lymphocytes (Fig. 1). The only exception was another case of leishmaniasis which had high $\beta$ GS (173) and $82 \%$ of positive cells.

\section{Non-Hodgkin's lymphomas (Rappaport, 1966)}

The LN imprints from patients with DLWD, DLRD, and diffuse histiocytic (DH) lymphoma had a very low $\beta \mathrm{GS}$ and a low proportion of $\beta$-glucuronidase positive cells (Fig. 1). In only one case of DLPD were both the GS and the percentage of positive cells in the upper limits of normal (75 and 52 respectively).

\section{Hodgkin's disease}

In all cases the $\mathrm{LN}$ imprint lymphocytes showed a normal $\beta G S$ and percentage of positive cells regardless of the histological type or the disease (Lukes et al., 1966), including three cases of HD of the predominantly lymphocytic type (BGS 60-89). (Fig. 1). 


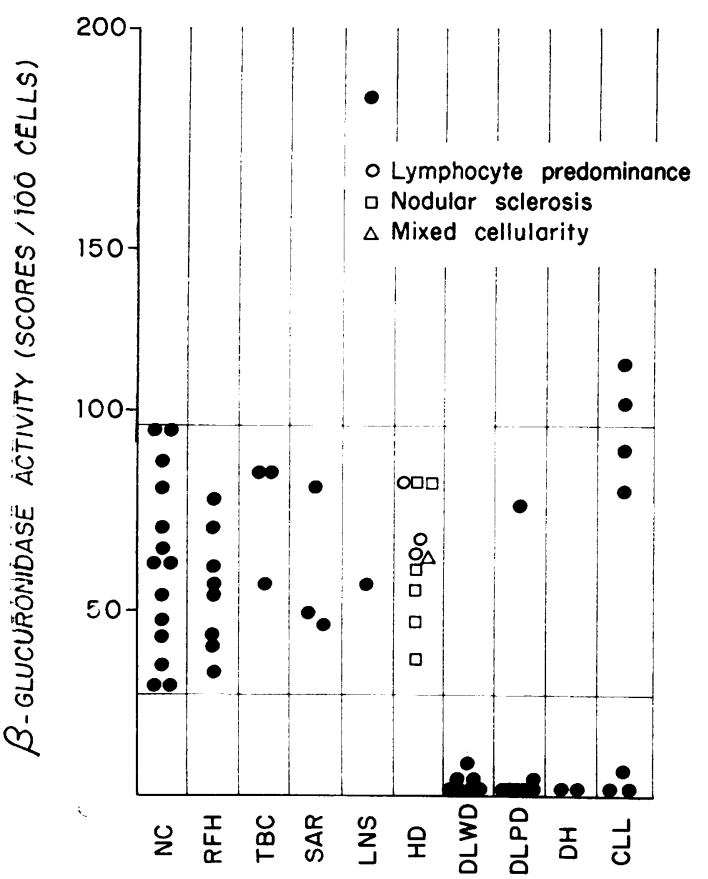

Fig. $1 \quad \beta$-Glucuronidase activity of LN imprint cells in various benign and malignant lymphadenopathies.

$N C=$ controls. $R F H=$ reactive follicular hyperplasia.

$T B C=$ tuberculosis. $S A R=$ sarcoidosis. $L N S=$ leishmaniasis. $H D=$ Hodgkin's disease. $D L W D=$ diffuse lymphocytic, well differentiated. $D L P D=$ diffuse lymphocytic, poorly differentiated. $\mathrm{DH}=$ diffuse histiocytic. $C L L=$ chronic lymphocytic leukaemia.

\section{Chronic lymphocytic leukaemia}

Although the average $\beta G S$ (59) and the average percentage of positive lymphocytes (49) in the $\mathrm{LN}$ imprints of CLL were found to be within normal limits, three patients had a very low $\beta$ GS while four had a $\beta$ GS in the upper limits of normal (Fig. 1).

\section{$\beta$-gLUCURONIDASE ACTIVITY IN PERIPHERAL} BLOOD SMEAR LYMPHOCYTES

\section{Controls}

The average $\beta \mathrm{GS}$ of the peripheral blood smear control lymphocytes was $195.5 \pm 21 \cdot 3$ (range 164-224) and the average of positive cells $87 \cdot 4 \%$ (Fig. 2).

\section{Non-Hodgkin's lymphomas}

The $\beta$ GS and percentage of positive lymphocytes were both within normal limits in patients with DLPD, while in patients with DLWD the average $\beta G S$ and percentage of positive lymphocytes were lower $(81.4$ and $46.0 \%)$ compared with control lymphocytes (Fig. 2). No neoplastic cells were identifiable in the circulation in these cases.

\section{Hodgkin's disease}

The $\beta$ GS and the percentage of positive peripheral blood smear lymphocytes in HD were in the upper limits of normal $(212 \pm 42 \cdot 0$ and $88.5 \%$ respectively).

\section{Chronic lymphocytic leukaemia}

The circulating lymphocytes in four of the five patients with CLL had a lower $\beta$ GS than the controls, while the $\beta \mathrm{GS}(178)$ and the proportion of positive cells $(66 \%)$ of the fifth patient were within normal limits (Fig. 2).

\section{Discussion}

Significant differences in acid phosphatase and $\beta$-glucuronidase activities in B- and T-lymphocyte/ haematopoietic malignancies have been found by immunological and cytoenzymological techniques (Catovsky et al., 1974a; Brouet et al., 1975;

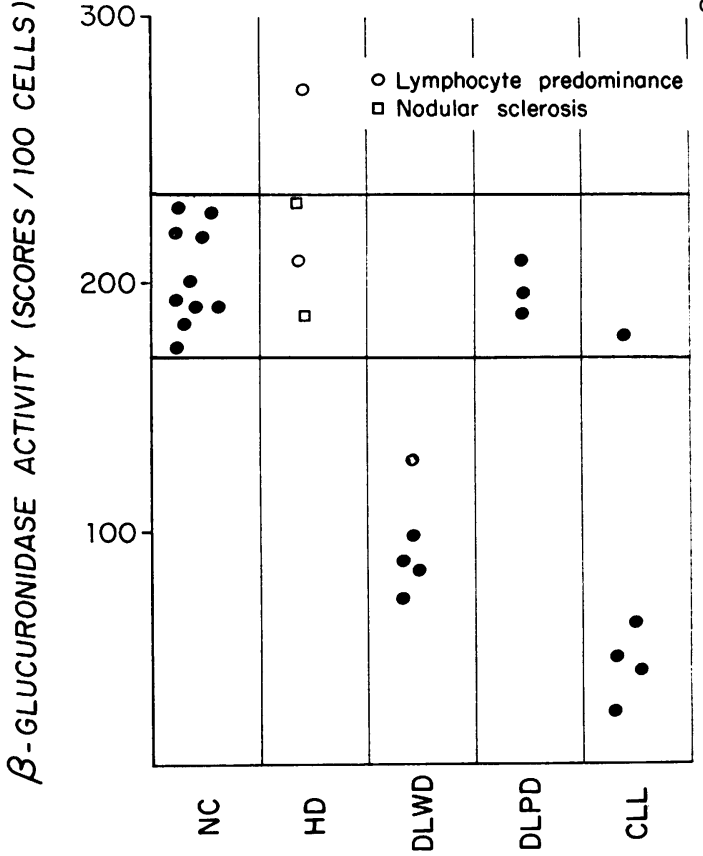

Fig. $2 \beta$-Glucuronidase activity of peripheral blood lymphocytes in various benign and malignant lymphadenopathies. 
Catovsky, 1975; Ritter et al., 1975; Stein et al., 1976; Wehinger and Möbius, 1976). Thus a high $\beta$-glucuronidase activity has been found in T-cell CLL and a low enzyme activity in B-cell CLL (Brouet et al., 1975). In addition, Sezary's cells, known to be $\mathrm{T}$-cell in origin, were also found to contain an increased $\beta$-glucuronidase activity (Flandrin and Daniel, 1974). Tamaoki and Essner (1969) reported positive acid phosphatase and $\beta$-glucuronidase reactions in the T-lymphocyte zone in $\mathbf{L N}$ and spleen using frozen sections from man and experimental animals, while the B-lymphocyte zones were negative for both reactions.

Almost all our patients with non-Hodgkin's lymphomas (DLWD, DLPD, DH) had a very low $\beta$-glucuronidase activity in the LN imprint cells. Nearly all non-Hodgkin's lymphomas have been classified as B-cell in origin (Stein et al., 1972; Aisenberg and Long, 1975; Lukes and Collins, 1975; Preud'Homme et al., 1975; Braylan et al., 1976). Further studies and correlations with B- or T-cell type on the same material will show whether measurement of $\beta$-glucuronidase activity can be used to distinguish these malignant lymphomas. In this context it may be of interest that although no great differences in acid phosphatase and $\beta$-glucuronidase activity of normal $B$ and $T$ peripheral blood lymphocytes were found by biochemical and cytochemical methods a very low $\beta$-glucuronidase activity was observed in B lymphocytes from tonsil compared with $\mathrm{T}$ lymphocytes from tonsil (Pangalis et al., 1977a). The neoplastic cells showed $\beta G S$ in the upper limits of normal in only one case of DLPD in our series of non-Hodgkin's lymphomas. This was in a 17-year-old boy who presented with mediastinal enlargement and cervical lymphadenopathy. Both the LN sections and imprints showed the picture of lymphoblastic lymphoma (Nathwani et al., 1976) of the convoluted type, a neoplasm that has been reported to be of T-lymphocyte origin (Barcos and Lukes, 1975; Stein et al., 1976).

We found a normal $\beta$ GS in the HD LN imprint lymphocytes independently of the histological type of the disease. This was significantly different from the $\beta G S$ of DLWD LN imprint lymphocytes, in which enzyme activity was very low. This difference between HD and DLWD may help in differential diagnosis, particularly because a marked scarcity of Reed-Sternberg cells in HD of the predominantly lymphocytic type may result in an erroneous diagnosis of DLWD (Berard and Dorfman, 1974).

In three out of our seven patients with CLL the LN imprint lymphocytes had a low $\beta$ GS while in the remaining four the enzyme activity was in the upper limits of normal. Platt and Platt (1971) reported a high $\beta$-glucuronidase activity in LN imprints of CLL, while Salvidio and Baldini (1965), by a biochemical method, found a low $\beta$-glucuronidase activity in lyophilised human spleens and lymph nodes in cases of CLL. These observations and our findings indicate that in LN lymphocytes in CLL other factors influence $\beta$-glucuronidase activity. Possibly an increased residual T-lymphocyte population in some cases results in a normal $\beta$ GS (Catovsky et al., 1974b; Braylan et al., 1976; Davis, 1976).

Generally our findings on the $\beta \mathrm{GS}$ in the peripheral blood lymphocytes are in agreement with previous reports (Anlyan et al., 1950; Follette et al., 1952; Yam and Mitus, 1968; Douglas et al., 1973; Westerhausen, 1973; Flandrin and Daniel, 1974; Woessner et al., 1974). Our most interesting observation was that the $\beta \mathrm{GS}$ was three times higher in the peripheral blood lymphocytes than in the LN lymphocytes in the controls and in patients with HD. This may be because of a different type of lymphocyte composition (B and $\mathrm{T}$ ) or because the functional condition or maturation of the peripheral blood lymphocytes differed from that of the LN lymphocytes. The latter possibility is supported by the fact that we found no significant difference in $\beta$-glucuronidase activity in separated normal $\mathbf{B}$ and $\mathrm{T}$ blood lymphocytes while the $\beta$-glucuronidase activity has been found to be very low in B tonsil lymphocytes compared with that in $\mathrm{T}$ tonsil lymphocytes (Pangalis et al., 1977a).

Our results are preliminary ones and a study of more cases in each group seems necessary. Nevertheless, they suggest that measurement of $\beta$-glucuronidase activity in $\mathrm{LN}$ imprint lymphocytes may help to distinguish certain types of malignant lymphomas from each other as well as from benign lymphadenopathies.

\section{References}

Aisenberg, A. C., and Long, J. C. (1975). Lymphocyte surface characteristics in malignant lymphoma. American Journal of Medicine, 58, 300-306.

Anlyan, A. J., Gamble, J., and Hoster, H. A. (1950). $\beta$ glucuronidase activity of the white blood cells in human leukaemias and Hodgkin's disease. Cancer, (Philad.), 3, 116-123.

Barcos, M. P., and Lukes, R. J. (1975). Malignant lymphoma of convoluted lymphocytes: A new entity of possible T-cell type. In Conflicts in Childhood Cancer: An Evaluation of Current Management, Vol. 4, edited by L. F. Sinks and J. O. Godden, pp, 147-178. Alan R. Liss, Inc., New York.

Berard, C. W., and Dorfman, R. F. (1974). Histopathology of malignant lymphomas. Clinics in Haematology, 3, 39-76.

Braylan, R. C., Jaffe, E. S., Burbach, J. W., Frank, M. M., Johnson, R. E., and Bernard, C. W. (1976). Simil- 
arities of surface characteristics on neoplastic welldifferentiated lymphocytes from tissues and from peripheral blood. Cancer Research, 36, 1619-1625.

Brittinger, G., König, E., Aberle, H. G., and Zimmerschitt, E. (1970). Lysosomal Enzyme in Blutlymphozyten von Gesunden und Patienten mit chronischer Lymphadenose bei kurzdauernder unspezifischer Stimulierung in vitro. Schweizerische medizinische Wochenschrift, 100, 341-344.

Brouet, J. C., Flandrin, G., Sasportes, M., Preud'Homme, J. L., and Seligmann, M. (1975). Chronic lymphocytic leukaemia of T-cell origin. Immunological and clinical evaluation in eleven patients. Lancet, 11, 890-893.

Catovsky, D. (1975). T-cell origin of acid-phosphatasepositive lymphoblasts (Letter). Lancet, 11, 327-328.

Catovsky, D., Galetto, J., Okos, A., Miliani, E., and Galton, D. A. G. (1974a). Cytochemical profile of B and $T$ leukaemic lymphocytes with special reference to acute lymphoblastic leukaemia. Journal of Clinical Pathology, 27, 767-771.

Catovsky, D., Miliani, E., Okos, A., and Galton, D. A. G. (1974b). Clinical significance of T-cells in chronic lymphocytic leukaemia. Lancet, 11, 751-752.

Crowder, J. G., and White, A. C. (1968). Selective changes in white cell lysosomal enzymes in man. American Journal of Medical Science, 255, 327-335.

Davis, S. (1976). The variable pattern of circulating lymphocyte subpopulations in chronic lymphocytic leukemia. New England Journal of Medicine, 294, 1150-1153.

Douglas, S. D., Cohnen, G., König, E., and Brittinger, G. (1973). Lymphocyte lysosomes and lysosomal enzymes in chronic lymphocytic leukaemia. Blood, 41, 511-518.

Flandrin, G., and Daniel, M. T. (1974). $\beta$-glucuronidase activity in Sezary cells. Scandinavian Journal of Haematology, 12, 23-31.

Follette, J. H., Valentine, W. N., and Lawrence, J. S. (1952). The $\beta$-glucuronidase content of human leukocytes in health and in disease. Journal of Laboratory and Clinical Medicine, 40, 825-840.

Hayashi, M., Nakajima, Y., and Fishman, W. H. 1964). The cytologic demonstration of $\beta$-glucuronidase employing naphthol AS-BI glucuronide and hexazonium pararosanilin. A preliminary report. Journal of Histochemistry and Cytochemistry, 12, 293-297.

Lorbacher, P., Yam, L. T., and Mitus, W. J. (1967). Cytochemical demonstration of $\beta$-glucuronidase activity in blood and bone marrow cells. Journal of Histochemistry and Cytochemistry, 15, 680-687.

Lukes, R. J., and Collins, R. D. (1975). A functional classification of malignant lymphomas. In The Reticuloendothelial System: (IAP Monographs, No. 16), edited by J. W. Rebuck, C. W. Bernard and M. R. Abell, pp. 213-242. Williams and Wilkins, Baltimore.

Lukes, R. J., Craver, L. F., Hall, T. C., Rappaport, H., and Ruben, P. (1966). Report of the nomenclature committee. Cancer Research, 26, 1311.

Nathwani, B. N., Kim, H., and Rappaport, H. (1976). Malignant lymphoma, lymphoblastic. Cancer (Philad.), 38, 964-983.

Pangalis, G. A., Kuhl, W., Waldman, S. R., and Beutler,
E. (1977a). Acid hydrolases in normal B and T blood lymphocytes. British Journal of Haematology. In press.

Pangalis, G. A., Nathwani, B. N., and Rappaport, H. (1977b). Malignant lymphoma, well differentiated lymphocytic: its relationship with chronic lymphocytic leukemia and macroglobulinaemia of Waldenström. Cancer (Philad.), 39, 999-1010.

Platt, D., and Platt, M. (1971). Biochemischer und histochemischer Nachweis der $\beta$-Glukuronidase und $\beta$-Azetylglukosaminidase in normalen und pathologisch veränderten menschlichen Lymphknoten. Blut, 22, 12-18.

Preud'Homme, J. L., Brouet, J. C., and Seligmann, J. (1975). Lymphocyte membrane markers in human lymphoproliferative diseases. In Membrane Receptors of Lymphocytes: Inserm Symposium, edited by $\mathrm{M}$. Seligmann, J. L. Preud'Homme, and F. M. Kourilsky, pp. 417-429. North Holland Publishing Company, Amsterdam; American Elsevier Publishing Company, New York.

Rappaport, H. (1966). Tumors of the Hematopoietic System (Atlas of Tumour Pathology, Section III, Fascicle 8). Armed Forces Institute of Pathology, Washington, DC.

Ritter, J., Gaedicke, G., Winkler, K., Beckmann, H., and Lanabeck, G. (1975). Possible T-cell origin of lymphoblasts in acid-phosphatase-positive acute lymphatic leukemia (Letter). Lancet, $2,75$.

Salvidio, E., and Baldini M. (1976). Quantitative dఱీ terminations of phosphatases and $\beta$-glucuronidase activity in spleen from patients with myelofibrosis and myeloid metaplasia and other hematological disorders In Current Research in Leukemia, edited by F. G. J. Hayhoe, pp. 241-252. Cambridge University Press, London.

Stein, H., Lennert, K., and Parwaresch, M. R. (1972). Malignant lymphomas of B-cell type. Lancet, 2, 855-857.

Stein H., Petersen, N., Gaedicke, G., Lennert, K., and Lanbeck, G. (1976). Lymphoblastic lymphoma of convoluted or acid phosphatase type-A tumor of $\mathrm{T}$ precursor cells. International Journal of Cancer, 17, 292-295.

Tamaoki, N., and Essner, E. (1969). Distribution of acid phosphatase $\beta$-glucuronidase and $\mathrm{N}$-acetyl- $\beta$-glucosaminidase activities in lymphocytes of lymphatic tissues of man and rodents. Journal of Histochemistry and Cytochemistry, 17, 238-243.

Wehinger, H., and Möbius, W. (1976). Cytochemical studies on $T$ and $B$ lymphocytes and lymphoblasts with special reference to acid phosphatase. Acta Haematologica, 56, 129-136.

Westerhausen, M. (1973). Constatations cytochimiques et immunologiques dans les leucémies lymphoỉdes chroniques (LLC). Nouvelle Revue Française d'Hématologie, 13, 398-400.

Woessner, S., Millá, F., and Rozman, C. (1974). A study of lymphocytic $\beta$-glucuronidase in various benign and malignant lymphatic processes. Acta $\stackrel{\$}{+}$ Haematologica, 51, 84-90.

Yam, L. T., and Mitus, W. J. (1968). The lymphocyte $\beta$-glucuronidase activity in lymphoproliferative disorders. Blood, 31, 480-489. 